\title{
Noneducational board games in University Education. Perceptions of students experiencing Game-Based Learning methodologies
}

\author{
Juan Luis Gonzalo-Iglesia, Natàlia Lozano- \\ Monterrubio \& Jordi Prades-Tena
}

Abstract:

In the recent years, most academic literature of Game-Based Learning (GBL) has provided in-depth knowledge of the characteristics of games that foster participative learning and that increase the level of motivation of students. In addition, most of these studies have focused on videogames. Consequently, few academic research has centred in the potentialities of noneducational board games as teaching methodologies. The current paper intends to contribute to filling this gap with an exploratory investigation with a two-stage process. The first involved three experimental interventions in six bachelor degree courses for Communication and Biochemistry studies ( $n=196$ students). In these interventions, teachers introduced commercial board games that were related to the content of the courses and aimed students to play. The second stage gathered data-driven results from an online survey among the students who had participated in the GBL interventions ( $n=87)$. The study analyses the perceptions of students in relation to their preferences in teaching methodologies, the suitability of board games in class, their reasons for feeling motivated while playing and the skills experienced during the GBL sessions. Results reveal that the sessions generated high perception levels of engagement and motivation as well as the development of transversal skills such as teamwork and communication.

Keywords:

game-based learning; board games; motivation; university education. 


\title{
Juegos de mesa no educativos en la universidad. Percepciones de los estudiantes sobre su experiencia con metodologías de aprendizaje basado en juegos
}

\begin{abstract}
Resumen: En los últimos años, la literatura académica sobre el aprendizaje basado en juegos (ABJ) ha centrado sus investigaciones en las características de los juegos que fomentan el aprendizaje participativo y que aumentan el nivel de motivación de los estudiantes. Además, muchos de estos estudios se focalizan en el uso de los videojuegos como elementos docentes. No obstante, existen pocas investigaciones científicas que evalúen las potencialidades de los juegos de mesa no educativos como métodos docentes. Este artículo pretende contribuir a llenar ese vacío con una investigación exploratoria realizada en dos fases. En la primera, se desarrollaron tres intervenciones experimentales en seis asignaturas de los grados universitarios de los estudios de Comunicación y Bioquímica ( $n=196$ estudiantes). En estas intervenciones, los profesores trajeron juegos de mesa comerciales relacionados con el contenido de las asignaturas e hicieron jugar a los estudiantes. En la segunda fase del estudio, se realizó una encuesta online a los participantes de las intervenciones $(n=87)$. Esta procuraba obtener información sobre las preferencias de los estudiantes en cuanto a metodologías de aprendizaje, sus percepciones sobre la idoneidad del uso de los juegos de mesa en las aulas universitarias, sus razonamientos sobre qué les había motivado al jugar y las habilidades trabajadas durante las sesiones de ABJ. Los resultados muestran que los participantes se sintieron altamente motivados con las sesiones y que consideran que desarrollaron habilidades transversales como el trabajo en equipo y la comunicación.
\end{abstract}

Palabras clave: aprendizaje basado en juegos; juegos de mesa; motivación; educación universitaria.

\section{Jogos de tabuleiro não educativos na universidade. Percepções dos alunos sobre sua experiência com metodologias de aprendizagem baseada em jogos}

Resumo: Nos últimos anos, a literatura académica sobre aprendizagem baseada em jogos (ABJ) concentrou as suas pesquisas nas características dos jogos que promovem a aprendizagem participativa e aumentam o nível de motivação dos alunos. Além disso, muitos desses estudos colocam a tónica no uso de videojogos como elementos de ensino. No entanto, existem poucas pesquisas científicas que avaliam as potencialidades dos jogos de tabuleiro não-educacionais como métodos de ensino. Este artigo pretende contribuir para preencher esta lacuna com uma investigação exploratória realizada em duas fases. Na primeira, foram desenvolvidas três intervenções experimentais em seis disciplinas dos cursos universitários de Comunicação e Bioquímica ( $n=196$ alunos). Nessas intervenções, os professores apresentaram jogos de tabuleiro comerciais relacionados ao conteúdo programático e convidaram os alunos a jogar. Na segunda fase do estudo, foi realizado um questionário online aos participantes destas intervenções $(n=87)$. Objetivou-se obter informações sobre as preferências dos alunos em relação às metodologias de aprendizagem, as suas percepções sobre a adequação do uso de jogos de tabuleiro nas salas de aula das universidades, as razões pelas quais se sentiram motivados para jogar e as habilidades trabalhadas durante as sessões de ABJ. Os resultados demonstram que os participantes se sentiram altamente motivados com as sessões e consideraram que desenvolveram habilidades transversais, como trabalho em equipa e comunicação.

Palavras-chave: aprendizagem baseada em jogos; jogos de tabuleiro; motivação; educação universitária

\section{Jeux de société non éducatifs à l'université. Perceptions des étudiants de leur expérience avec les méthodologies d'apprentissage par le jeu}

Résumé: Au cours des dernières années, la plupart des publications académiques sur l'Apprentissage Par le Jeu (APJ) ont permis de mieux connaître les caractéristiques des jeux qui favorisent l'apprentissage participatif et qui augmentent le niveau de motivation des élèves. La plupart de ces études se sont concentrées sur les jeux vidéo, par conséquent, peu de recherches universitaires se sont basées sur les potentialités des jeux de société non éducatifs en tant que méthodologies d'enseignement. Le présent document prétend contribuer à combler cette lacune en procédant à la réalisation d'une enquête exploratoire. Cette enquête a été divisée en deux étapes. La première a impliqué trois interventions expérimentales dans six cours de licence de Communication et de Biochimie $(n=196$ étudiants). Dans le cadre de ces interventions, les enseignants ont introduit des jeux de société commerciaux liés au contenu des cours et destinés aux élèves. La deuxième étape a permis de recueillir des résultats basés sur des données provenant d'une enquête en ligne auprès des étudiants ayant participé aux interventions APJ ( $n=87$ ). L'étude analyse les perceptions des étudiants par rapport à leurs préférences dans les méthodologies d'enseignement, l'adéquation des jeux de société en classe, les raisons pour lesquelles ils se sentent motivés pendant le jeu et les compétences acquises lors des sessions APJ. Les résultats révèlent que les sessions ont généré des niveaux élevés de perception sur l'engagement et la motivation ainsi que le développement de compétences transversales telles que le travail en équipe et la communication.

Mots-clés: apprentissage par le jeu; jeux de société; motivation; enseignement universitaire 


\section{Introduction}

Play and games have traditionally been linked to teaching. More recently, they are presented as a strategic innovation tool to improve the learning process. In the last decade, several theoretical and practical perspectives have emerged that approach this issue such as gamification (Deterding, et al., 2011; Kapp, 2012), pervasive games (Montola et al., 2009), serious games (Ritterfeld et al., 2009) or Game-Based Learning (Tobias, Fletcher \& Wind, 2014). Although they offer different approaches, their nexus is the usage of the principles of games or even the games themselves as tools to enhance learning and increase the motivation and engagement of students. All of these methodologies place students at the core of their own learning process. In addition to improved motivation, games in the learning process intend to support participative, experimental and cooperative techniques that encourage $21^{\text {st }}$ century skills (critical thinking, creativity, collaboration and communication).

Although boundaries between the concepts are in many cases diffused, the terminological debate is placed in the pedagogical/ludic axes and created games/gaming experience. For example, while gamification is considered the design of activities which use "game-based mechanics, aesthetics and game thinking to engage people, motivate action, promote learning, and solve problems" (Kapp, 2012) and are more concerned about the global experience of the participants than in the usage of a particular game (Cornellà \& Estebanell, 2017), serious games put emphasis on the learning objectives rather than in the playful structure. As Wu \& Lee (2015, p. 414) exemplify:

Climate change games are considered 'serious games' that are designed to have underlying objectives beyond mere entertainment such as instructional goals. Game characteristics such as goals, rules, or the use of fantasy not only promote player engagement, but also influence learning.

Within this debate, some authors see contradictory uses of games in education, because they would be the opposite of serious (Wechselberger, 2013). On the other hand, Rubio (2013) states that educational games do not always achieve their goals because they often neglect to integrate the most playful aspects of game design and focus on the pedagogical tool. Many experts see the element of play as central to the effectiveness of learning with games (Gee, 2008). Consequently, the effective design of game characteristics (interaction, decision-making, fun, challenge, competition, etc.) can arouse greater interest in the participants, thus contributing to the learning process.

Within all these trends, Game-Based Learning (GBL) is a methodology based on the creation of games and simulations or using existing ones, preferably digital, as teaching resources in the classroom. Close to the serious games technique, its main 
difference would be the usage of playful characteristics seen in noneducational games to produce and improve the user's learning experience. A relevant aspect to consider is that knowledge and game culture are increasingly popular with each new generation of learners. This means working with tools that are familiar to many students. As Hamari et al. (2016, p.176) state:

Serious games present the opportunity for indwelling, when familiarity with ideas, practices, and processes are so ingrained that they become second nature. However, because these ideas, practices, and processes are components of tacit knowledge, they are difficult to measure.

These learning instruments are not exclusive to primary and secondary levels of education. They are also used in multiple ways in higher education. Although most gamification and GBL experiences are based on digital resources and videogames (de Freitas, 2006; Zin, Yue, \& Jaafar, 2009; Crocco, Offenholley \& Hernández 2016), board games are experiencing a new boom and their diverse options open new possibilities to the usage of physical resources in higher education classrooms. In this sense, new commercial board games are a potentially valuable resource and a valid option for teaching and learning opportunities in higher education.

However, there is a gap in academic studies focused on the usage of board games as a tool for GBL or gamification. For this reason, our objective is to analyse and evaluate the potential impacts of Game-Based Learning methodology with commercial board games in higher education with a special focus on students' motivation.

\section{Advantages of Using Contemporary Board Games at Higher Education}

For the purpose of this study, contemporary board games refer to those commercial board games that have appeared in the last twenty years and include titles as Catan (1995), Cascassone (2000) or Ticket to Ride (2004). This new generation of games focuses on the playful elements of the game that aim to reach a transversal and wide public. This new universe of games is a fruitful research area in GBL as it balances the tension between learning objectives, ludic dimension and the game experience.

Following this framework, several examples of the application of analogic noneducational games in higher education were identified. Huang \& Levinson (2012) assess the usage of commercial games such as Air Baron, Metro, Rail Baron, Rail Tycoon, Empire Builder, China Rails and 1870 to learn the planning of transport systems in civil engineering. Berland \& Lee (2011) use the game Pandemic to analyse how logical and computational thinking processes of collaborative strategy games players work. And, Castronova \& Knowles (2015) have changed the game $\mathrm{CO}_{2}$ to explain and discuss the 
functioning of climate policies. There is also an inverse case such as KEEP COOL, which is a board game that was specifically designed to spread climate change information among "families, students, journalists, and politicians, environmentally concerned and game enthusiasts, consultants, and nongovernmental organizations (NGOs)" (Eisenack, 2012, p.329) and that later became marketable.

Apart from the terminological complexity of the field or the specific format of games, studies suggest that games may produce some advantages in education such as its potential for motivation, the possibility to generate an active learning, its impact in personal and emotional skills (overcoming challenges, self-confidence...) which favour interaction and sociability and allow learning by competencies (Romero y Gebera, 2015) as well as the ability to offer a general overview for complex issues. But, above all, these games are designed to place players at the core of the learning process (Garris, Ahlers \& Driskell, 2002).

[Games] help to motivate students and to involve them into the teaching and learning process by providing the necessary tools to put them in the centre of the teaching action and making them main characters of their learning (Cornellà \& Estebanell, 2017).

Nevertheless, demonstrable evidence does not always support these statements and some authors claim that more studies should focus on the evaluation of measurable effects (Crocco, Offenholley \& Hernández 2016, p.406).

In cases where board games were used, some of the most valuable aspects cited are direct interaction between players and presence:

It should be a board and not a computer game, as face-to-face communication is a more appropriate way to simulate real-world climate negotiations. Moreover, a face-to-face game encourages discussion and questioning; thereby, direct experience from the game provides a natural starting point for debriefing (Eisenack, 2012, p. 333).

Other authors valued aspects that were directly related to the physicality of games and its components because avoiding the complexity of digital systems and a technological mediation can allow more flexibility with the rules or can deepen the psychological aspects of the simulation (Meijer, 2015, p.531). On the other hand, Castronova \& Knowles (2015) argue that commercial games offer additional advantages due to their range of topics. In addition, the existing options on the market could be used as models for a modification or redesign that fit the desired learning goals. It is also important to note that using these games in the classroom may also be problematic as players 
need to know the rules and it is difficult to create a flowing learning curve due to the possible loss of participants' interest (Eisenack, 2012). These problems may become more pronounced with existing commercial games if the level of difficulty is not correctly valued (Huang \& Levinson, 2012).

Apart from evaluating the efficacy of these learning techniques, research has also contributed in-depth knowledge about students' learning perception of games as teaching methods at higher education and their consequences. Some studies about the specific usage of GBL state that students admitted "higher levels of interest, enjoyment and confidence compared to traditional methods" (Crocco, Offenholley \& Hernández 2016, p.407). It seems that as their motivation increases, immersion and engagement were also aspects identified and most valued by students (Vandercruysse et al., 2013; Hamari et al., 2016). However, most of these experiences applied to Digital GBL interventions. Consequently, more studies are needed to provide evidence related to students' perception of the usage of board games in university lectures.

\section{Methodology}

This investigation of Game-Based Learning experiences in higher education was conducted with an exploratory, two-stage process. The first stage involved three experimental interventions in three courses of six bachelor degrees involving 196 students of Universitat Rovira i Virgili (Tarragona, Spain). Students were enrolled in the following courses:

a. History and Structure of Communication — second year of the BA in Journalism (38 students), BA in Advertising and Public Relations (44 students) and BA in AudioVisual Communication (37 students),

b. Advertising Creativity — third year of the BA in Advertising and Public Relations 24 students) and

c. Legal, Social and Communicative Aspects of Biotechnology — fourth year of the BSc in Biotechnology (36 students), Double BSc in Computer Engineering and Biotechnology (6 students) and Double BSc in Biotechnology, Biochemistry and Molecular Biology (11 students).

The three interventions had different levels of application of Game-Based Learning according to the objectives and contents of the courses. These interventions will be detailed in the results.

The second stage of the research was data-driven. Results were gathered through an online survey among the students who participated in the experimental interventions, which included quantitative and qualitative questions with the objective to discover 
their previous assumptions about games and their usage as teaching methods at a university level; the perceived skills that were practiced during the GBL sessions; and their personal engagement in the courses after the experiment. The survey obtained 87 responses. Although the results of the survey have limited representation due to the number of participants, the qualitative data collected relevant information that also contextualises the results and contributes to the study.

\section{Results}

\section{a) First Stage Process: Game-Based Learning Sessions}

As previously mentioned, the GBL sessions took place in the courses of History and Structure of Communication; Advertising Creativity and Legal, Social and Communicative Aspects of Biotechnology (see Table 1).

The impact of the board games differed in the three practices according to the teaching objectives and the time spent on the GBL tasks. In the case, of History and Structure of Communication, Game-Based Learning was used as a starting point for research about course content. Students experienced this method for a month whereas in Advertising Creativity, games were used in one session to spur imagination and creative writing among students. But, in Legal, Social and Communicative Aspects of Biotechnology, the objective was to show learners different ways to explore and communicate science. The premise was that current media environment should facilitate the comprehension of research by non-specialists and, when possible, to promote a two-way exchange and engagement between scientists, stakeholders and the whole public in order to improve the impact of the scientific research. Accordingly, GBL methodology took two sessions in this course. The former introduced the concept of Responsible Research and Innovation, which claims communication "from science in society to science for society, with society" (Owen et al. 2012, p.751) and the later presented the concept of Social Impact of Science:

"[...] we are talking about beneficial changes that will happen in the real world (beyond the world of researchers) as a result of your research. This can include 'negative impacts' such as evidence that prevents the launch of a harmful product or law. [...] Impacts occur through processes of knowledge exchange [management, sharing, co-production, transfer, brokerage, transformation, mobilisation, and translation] where new ideas are developed in relationship with the people who will put those ideas into practice" (Reed 2016, p.10). 
Apart from the aforementioned aims, the usage of GBL was also to encourage motivation among students by introducing more participative, social and innovative methods in class.

The GBL sessions in the course of History and Structure of Communication, the activity was scheduled within a month. Their objectives were to reach an experiential comprehension of the theoretical contents of the syllabus, to documentation search and to understand graphic design. As such, students were divided into groups and were introduced to the commercial board game Timeline of Asmodee, which organises famous events in a chronological line (inventions, music, history...). Once they played the original game, students had to select 20 key events in the history of communication within a specific thematic area (i.e. press, radio, advertising, internet...). Groups had to design and produce their own game elements (cards) that reproduced the original game. With the new cards from all groups, students created a new and unique game. It was used as a final stage when students put their acquired knowledge to test in a game session.

In the Advertising Creativity course, the objective for the use of GBL in class was to stimulate lateral thinking with two commercial board games Dixit of Libellud and Días de radio of Mont Tàber Edicions. The teaching session consisted of three parts. First, board games were played in small groups. Secondly, after two games (40-45 minutes), students were required to associate the concepts of a card of Dixit (picture) and Días de radio (word) with a commercial brand. The whole group had the same assignment: to write a story for a radio advertisement that contained the two selected concepts and created brand identity. Finally, each team shared their commercials with the rest of the group so that students could appreciate how prolific and different their ideas, stories and narrative styles were.

In the Legal, Social and Communicative Aspects of Biotechnology course, the commercial board games used were Cytosis, Peptide, Virulence and Covalence edited by Genius Games. As the students were in their fourth and last bachelor year, they had advanced knowledge of biotechnology. Thus, the main objective for the use of board games was not to support the acquisition of new knowledge in their specialities, but to show an original perspective from social sciences and humanities about how to communicate, transfer and socialise science to lay people in a ludic way. The teaching sessions consisted of splitting the students into groups to play the selected games. Once played, students had to assess the mechanics, design and motivators of the games. Finally, sessions ended with a debate about their opinions and considerations of how these could be useful in socialisation, Responsible Research and Innovation and Social Impact of Science concepts. 
Table 1. Courses, commercial board games used and teaching objectives of the three GBL interventions.

\begin{tabular}{|c|c|c|c|}
\hline Courses & Degrees & $\begin{array}{c}\text { Board games } \\
\text { used }\end{array}$ & $\begin{array}{c}\text { Specific teaching } \\
\text { objectives }\end{array}$ \\
\hline $\begin{array}{l}\text { History and } \\
\text { Structure of } \\
\text { Communication }\end{array}$ & $\begin{array}{c}\text { BA in Journalism } \\
\text { BA in Advertising and Public } \\
\text { Relations } \\
\text { BA in Audio-Visual } \\
\text { Communication }\end{array}$ & Timeline & $\begin{array}{l}\text { Experiential } \\
\text { comprehension of } \\
\text { the syllabus } \\
\begin{array}{c}\text { Documentation } \\
\text { search }\end{array} \\
\text { Graphic design }\end{array}$ \\
\hline $\begin{array}{l}\text { Advertising } \\
\text { Creativity }\end{array}$ & $\begin{array}{l}\text { BA in Advertising and Public } \\
\text { Relations }\end{array}$ & $\begin{array}{c}\text { Dixit } \\
\text { Días de Radio }\end{array}$ & $\begin{array}{l}\text { Creativity } \\
\text { Communicative } \\
\text { skills }\end{array}$ \\
\hline $\begin{array}{c}\text { Legal, Social and } \\
\text { Communicative } \\
\text { Aspects of } \\
\text { Biotechnology }\end{array}$ & $\begin{array}{c}\text { BSc in Biotechnology } \\
\text { Double BSc in Computer } \\
\text { Engineering and } \\
\text { Biotechnology } \\
\text { Double BSc in Biotechnology, } \\
\text { Biochemistry and Molecular } \\
\text { Biology }\end{array}$ & $\begin{array}{l}\text { Cytosis } \\
\text { Peptide } \\
\text { Virulence } \\
\text { Covalence }\end{array}$ & $\begin{array}{c}\text { Socialisation of } \\
\text { science } \\
\text { Awareness of } \\
\text { Responsible } \\
\text { Research and } \\
\text { Innovation (RRI) } \\
\text { and Social Impact } \\
\text { of Science (SIS) } \\
\text { concepts }\end{array}$ \\
\hline
\end{tabular}

Source: Authors.

\section{b) Second Stage Process: Surveys}

In order to evaluate how students perceived the introduction of these practices, an online survey was sent to the students who had participated in the Game-Based Learning sessions. A total of 87 responses were collected.

\section{Profile of the Sample}

Most of the participants were students of Communication Studies degrees (63.2\%) and the rest were students in Biochemistry Studies (36.8\%). Within these fields, the sample is mostly represented by the students in the BA in Advertising and Public Relations area (33.3\%), followed by students from the BSc in Biotechnology (27.6\%) and 
BA in Journalism (20.7\%) areas. Fewer responses were collected from students in the BA in Audio-Visual Communication (9.2\%), Double BSc in Biotechnology, Biochemistry and Molecular Biology (6.9\%) and Double BSc in Computer Engineering and Biotechnology $(2.3 \%)$ areas.

In their leisure time, respondents reported that they were more used to play board games $(64.4 \%)$ rather than videogames $(47.1 \%)$, but videogamers reported that they played more frequently with $25.3 \%$ who reported that they played videogames at least once per week as compared to $14.9 \%$ of board gamers. And, among these weekly videogamers, $6.9 \%$ reported that they played daily, whereas none of the participants reported playing board games every day. These figures help to predict that there is a predisposition of participants to be open-minded about the usage of games in higher education (see Figure 1).

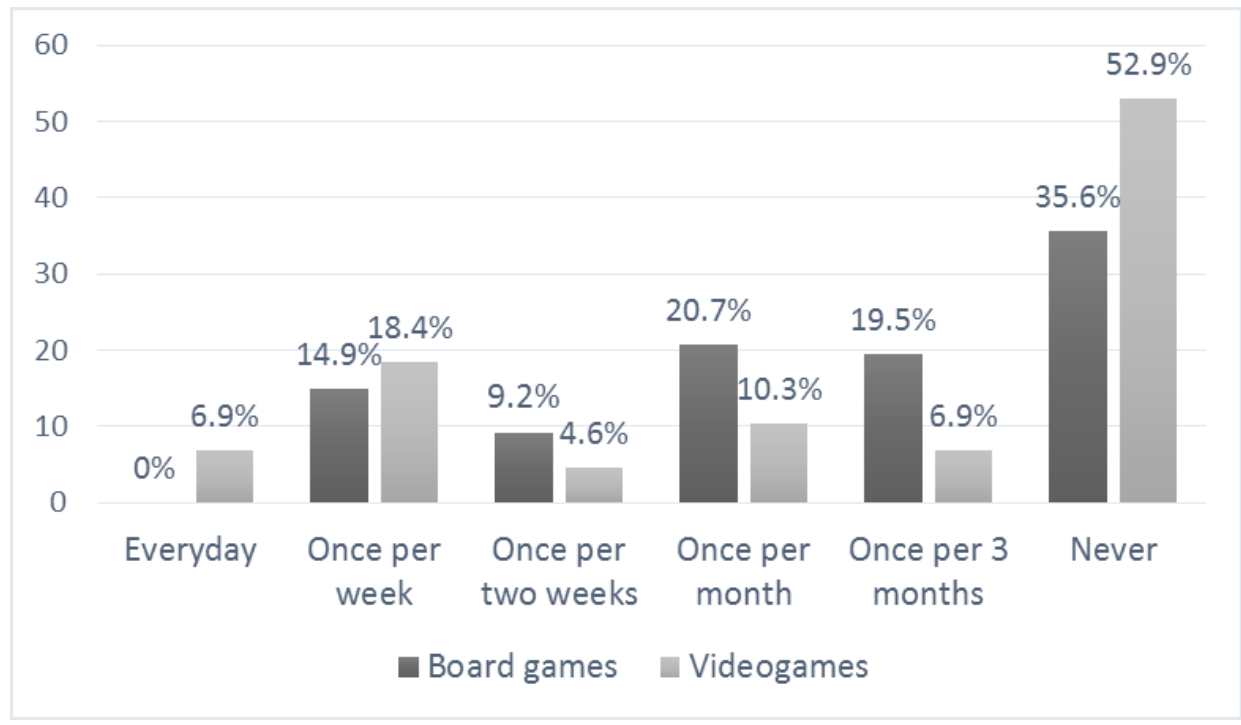

Source: Authors.

Figure 1. Gaming frequency in board games and videogames of the sample.

\section{Teaching Methodologies at University}

When survey respondents were asked about what teaching methods students experienced more frequently at their university, students chose masterclasses (95.4\%) and student oral expositions of the contents (79.3\%) as the most common methods. 
However, these were the least preferred when asked about what teaching methods students would wish to receive at higher education (masterclasses received $10.3 \%$ and student oral expositions 9.2\%). Workshops and experimentation in labs (51.7\%) and Problem-Based Learning (23\%) were reported as the third and fourth most extended teaching methods at university. In these cases, they are also preferred by students (47.1\% workshops and experimentation and $43.7 \%$ for Problem-Based Learning).

Methodologies that were more expected at university were simulations and role playing games (67.8\% of interested students) and Game-Based Learning (64.4\%) but they were not commonly reported in the respondents' current lectures $(16.1 \%$ of participants found simulations and role playing in their lectures and $10.3 \%$ selected Game-Based Learning). Other methods that are not commonly used in lectures nor extensively desired among students were Flipped-Classroom, Gamification and Transversal Projects. Authors of this study deduct that these innovative methods may have less support because students who participated in the survey may not have sufficient understanding of these concepts (see Figure 2).

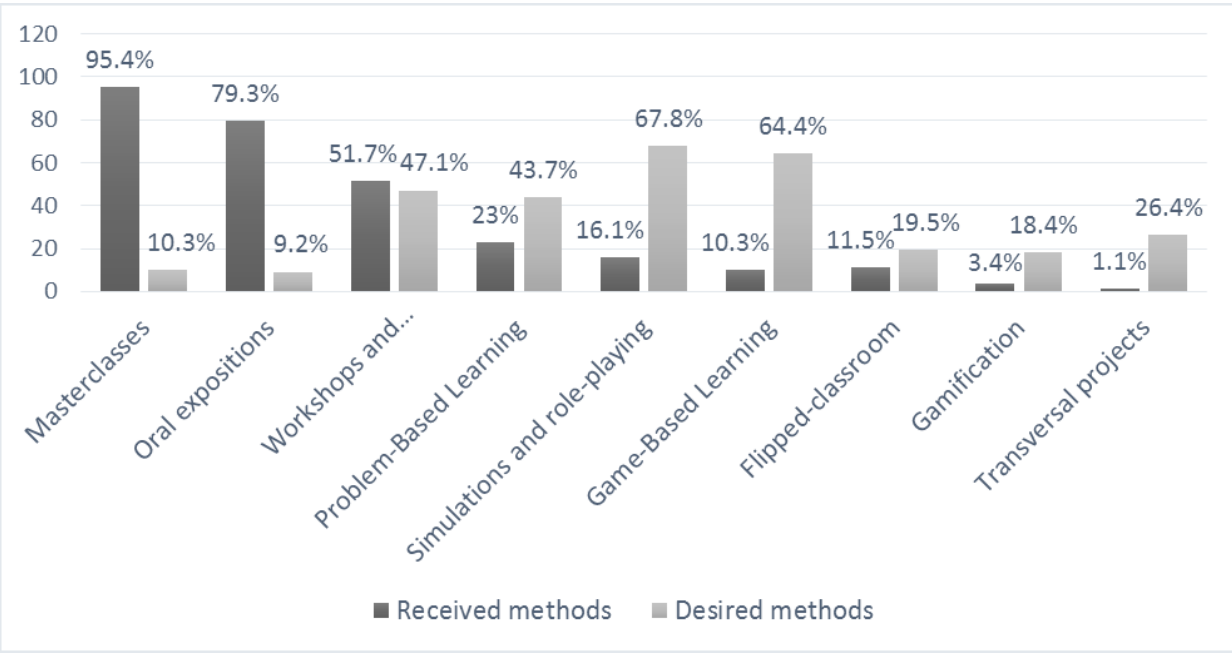

Source: Authors.

Figure 2. Comparison between received and desired teaching methods at university 


\section{Perceptions about Games as a Teaching Method}

Before asking about the GBL sessions that were field-tested for the study, the researchers wanted to identify any participants' prejudices about the use of board games in higher education, such as considering the role of play as a childish activity or that videogames connect better with a younger demographic. Therefore, they were asked to answer their level of agreement about several assumptions.

Results clearly show that a majority of participants reject the assumptions that "playing is an activity reserved only for children" (87.4\%) and that "playing is an unproductive activity" (77\%). A smaller majority of participants completely disagree with the assumptions that "games detract prestige to higher education" (59.8\%) and that "at university students should not play to board games" (57.5\%). In fact, 55.2\% of the sample highly or completely agrees with the statement that "Game-Based Learning methods could support regular master classes" and 29.8\% of the participants reported that they were neutral about the statement.

About the presumption that youngsters prefer videogames to board games, results of this study show the contrary. There is a slight preference for analogic games rather than digital ones as $41.4 \%$ of participants highly or completely agree with the assumption that "Game-Based Learning should use board games," whereas 34.5\% reported that they highly or completely agree with the statement that "Game-Based Learning should use videogames."

\section{Perceived Benefits of GBL Sessions with Board Games}

In the survey, $89.7 \%$ of students declared that they were motivated when the professor proposed the activity with board games, while only $5.7 \%$ of those polled were not motivated. The rest (4.6\%) did not respond.

This question was accompanied with a qualitative one about why students considered activities with board games as motivational or not. Their responses can be organised in nine different categories. Some of the quotes could be classified in more than one theme. Prioritised according to their number of responses, participants considered GBL activities in higher education as motivational under the following categories:

1. Active and new methodology. Game-Based Learning is a dynamic, different and not very extended methodology (mentioned by $34.2 \%$ of participants)

"It is a different methodology in which you can actively participate during all the time without switching off" (participant 2, BA in Journalism).

"It has motivated me because it has helped me to learn in a dynamic, different and entertaining way" (participant 31, BA in Journalism).

"It is a new way of teaching that I have never experienced before" (participant 56, BSc in Biotechnology). 
2. Funny methodology. Game-Based Learning allows student to learn while having fun (mentioned by $26.3 \%$ of participants).

"It motivates for several things: mainly to win, then you have fun with classmates and you can learn concepts without being stuck on a book and without the pressure of having an exam" (participant 46, BSc in Biotechnology).

"The activity motivated me because you have a lovely time, you laugh... and you learn and contents are better engraved in the memory" (participant 87, BA in Advertising and Public Relations).

3. Out of the routine methodology. Game-Based Learning helps to escape from the regular monotonous lectures (mentioned by $15.8 \%$ of participants).

"Itwas something differentfrom theroutineandaninteractivewaytolearn. It wasentertaining" (participant 43, Double BSc in Computer Engineering and Biotechnology).

"The activity was different to all the lectures I am used to and it was fun. I am sure that if there were introduced more board games and other alternative and active methodologies related with the syllabus, lectures would be more bearable and productive" (participant 62, BSc in Biotechnology).

4. Supportive methodology.Boardgamesmayhelptounderstand contents ofthecourse (mentioned by $13.1 \%$ of participants).

"It is a different way to learn where you put in practice several concepts that could not be understood with just a magister class" (participant 1, BA in Advertising and Public Relations).

"It is a different way of learning that suits people that find difficult to study" (participant 69, BA in Journalism).

5. Sociability. Games help me to mix with classmates (mentioned by $10.5 \%$ of participants).

"To me motivation comes when there is no pressure to do your best, and you have fun and you can relate with other people in an unusual way" (participant 58, BSc in Biotechnology).

"It has been dynamic and fun to play with classmates. What is more, you talk with people that you have never done it before" (participant 72, BA in Journalism).

6. Identification and design. Possibility to custom and personalise the game to feel it as its own (mentioned by $6.5 \%$ of participants).

"Because the cards of the game were very personal and you try your best in its design" (participant 6, BA in Advertising and Public Relations).

"Because designing the cards we learned a lot and when we had them printed we felt totally fulfilled because they were very similar to the original game" (participant 41, BA in Advertising and Public Relations).

7. New perspectives. Games open up new ways of thinking and perspectives (mentioned by $6.5 \%$ of participants). 
"It has been a different way to explore communicative and creative aspects" (participant 12, BA in Advertising and Public Relations).

"Games stimulate the brain, they are a good way of learning" (participant 7, BA in Advertising and Public Relations).

8. Setting challenges. Having objectives as mechanics for playing motivates to learn more (mentioned by $5.2 \%$ of participants).

"Because you are more eager to learn, and thus, win" (participant 9, BA in AudioVisual Communication).

"When you have a goal, you try harder, and it is more entertaining" (participant 27, BA in Audio-Visual Communication).

"I am a competitive person. Therefore, I concentrate and motivate myself to win. This favours my learning (since I pay more attention)" (participant 85, BA in Journalism).

9. Waste of time. Playing with board games at university is a waste of time (mentioned by $5.2 \%$ of participants).

"The activity did not motivate me, I think we did not learn anything, it was a waste of time" (participant 45, BSc in Biotechnology).

"The activity took me time that I had to invest in the projects of other subjects" (participant 49, Double BSc in Computer Engineering and Biotechnology).

Finally, students were asked about what skills that they used during the GBL sessions (see Figure 3). Here, the majority of participants reported that their teamwork (80.5\%) and communicative skills (78.2\%) were enhanced. A slightly smaller majority reported that their creativity $(67.8 \%)$, problem resolution (64.4\%), decision-making (64.4\%) and social skills (62.1\%) were used. Only one participant answered that no skill was enhanced. This participant also answered that he was not motivated at all by the GBL sessions. 


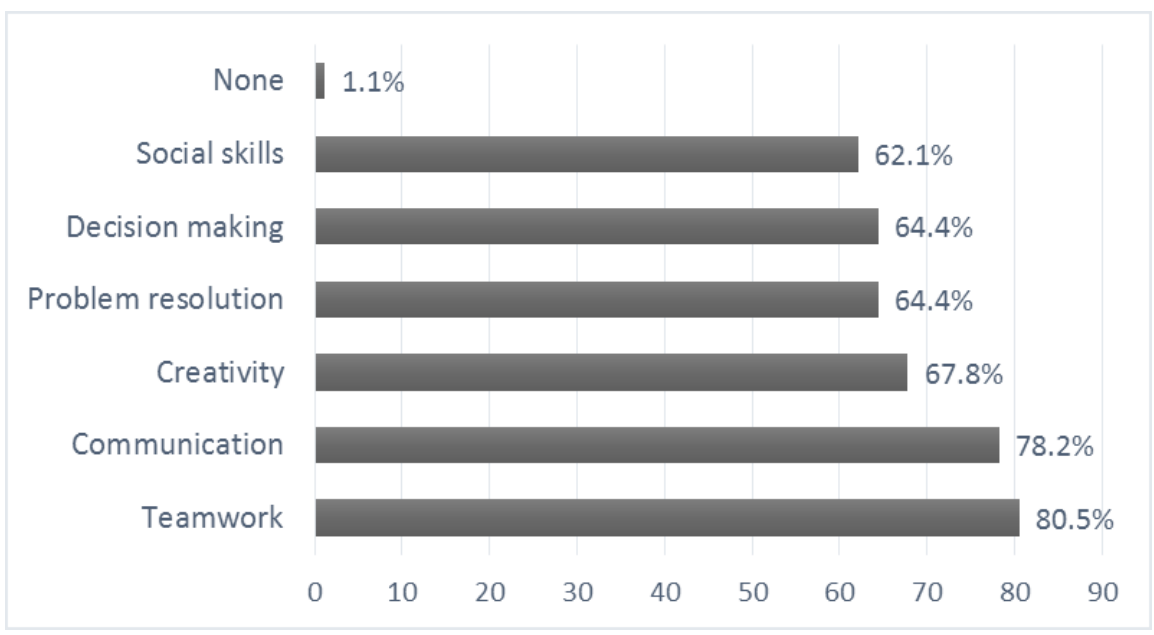

Source: Authors.

Figure 3. Perceived skills worked during the GBL sessions

\section{Conclusions}

Results of the survey indicate that students who participated in the Game-Based Learning interventions analysed in the study share a positive perspective on the usage of this GBL teaching methodology. Responses reveal that the sessions generated high perception levels of engagement and motivation.

On the one hand, participants appreciated the usage of active and dynamic learning techniques that supported, but were different from traditional lectures. Nonetheless the degree to which novelty and breaking with routine can be used to engage students in the learning process is still an open question. On the other hand, participants admitted that playful aspects such as entertainment, socialisation, competitiveness and the setting of challenges influenced their involvement in the activity. Students identified elements and mechanics of the game as main driving forces of engagement. Hence, it seems that the application of noneducational games with high levels of playful components that were strategically selected to fulfil the desired educational objectives contributed to the effectiveness of the activity.

One of the most interesting results of this study is that over a quarter of the students are conscious that GBL sessions allowed them to learn while having fun. Furthermore, a large majority do not have negative prejudices about the introduction of games in 
higher education classrooms, as they do not understand playing as an unproductive or childish activity.

In relation to skills, students also valued some abilities linked to the characteristics of the games (problem resolution or decision making) as very positive.

Nevertheless, it is important to note that a minority of participants did not feel motivated by the chosen teaching methodology, or even completely rejected it. It is necessary to bear in mind that Game-Based Learning needs complementary tools to include and encourage all participants in their learning processes. More research is needed to discover why some students were not attracted to the GBL teaching practice. Maybe they did not like the proposed games or do not understand the uses of GBL practices at the university or maybe there were other, external reasons that were not considered in this analysis.

In addition, this research indicates that several other issues remain to be studied in depth. For example, the results show that a significant number of participants had previous knowledge about games or were regular players either with board or videogames. Consequently, further research could measure the degree of familiarity with game culture as an element that facilitates engagement, motivation and, learning.

In this study, students recognised that skills like teamwork and communication were practiced through game play for learning. However, the relationship between the learning of theoretical content and other sorts of skills is in need of more research. More studies that analyse the impact of applying contemporary non-educational games in higher education over a long-term period would also contribute to the growing research base for the uses of games in the learning environment.

\section{References}

Berland, M., \& Lee, V. R. (2011). Collaborative strategic board games as a site for distributed computational thinking. International Journal of Game-Based Learning, 1(2), 65-81. https://doi. org/10.4018/ijgbl.2011040105

Castronova, E. \& Knowles, I. (2015). Modding board games into serious games: The case of Climate Policy. International Journal of Serious Games, 2(3), 41-62. https://doi.org/10.17083/ijsg.v2i3.77

Cornellà, P. \& Estebanell, M. (2017). GaMoodlification. Moodle al servicio de la gamificación del aprendizaje. Proceedings from CIVE'17: V Congreso Internacional de Videojuegos y Educación. Tenerife 7-9 June.

Crocco, F., Offenholley, K. \& Hernández, C. (2016). A Proof-of-Concept Study of Game-Based Learning in Higher Education. Simulation \& Gaming 47(4), 403-422. https://doi.org/10.1177/1046878116632484

Freitas, S. (2006). Learning in Immersive worlds. A review of game-based learning, JISC e-Learning Programme. Retrieved from http://researchrepository.murdoch.edu.au/id/eprint/35774/1/ gamingreport_v3.pdf 
Deterding, S., Dixon, D., Khaled, R., \& Nacke, L. (2011). From game design elements to gamefulness: defining gamification. Proceedings from 15th International Academic MindTrek Conference: Envisioning future media environments, 9-15, Tampere 28-30 September: ACM. https://doi. org/10.1145/2181037.2181040

Eisenack, K. (2012). A Climate Change Board Game for Interdisciplinary Communication and Education. Simulation \& Gaming 44(2-3), 328-348. https://doi.org/10.1177/1046878112452639

Garris, R., Ahlers, R., \& Driskell, J. E. (2002). Games, motivation, and learning: A research and practice model. Simulation \& gaming, 33(4), 441-467. https://doi.org/10.1177/1046878102238607

Hamari, J.; Shernoff, D.; Rowe, E.; Coller, B.; Asbell-Clarke, J. \& Edwards, T. (2016). Challenging games help students learn: An empirical study on engagement, flow and immersion in game-based learning. Computers in Human Behavior, 54, 170-179. https://doi.org/10.1016/j.chb.2015.07.045

Huang, A. \& Levinson, D. (2012). To game or not to game. Teaching transportation planning with board games. Transportation Research Record: Journal of the Transportation Research Board, 2307, 141149. https://doi.org/10.3141/2307-15

Kapp, K. M. (2012). The gamification of learning and instruction: game-based methods and strategies for training and education. San Francisco: John Wiley \& Sons.

Meijer, S. (2015). The Power of Sponges: Comparing High-Tech and Low-Tech Gaming for Innovation. Simulations \& Gaming 46(5), 512-535. https://doi.org/10.1177/1046878115594520

Montola, M.; Stenros, J. \& Waern, A. (2009). Pervasive games: Theory and design. San Francisco: Morgan Kaufmann Publishers Inc.

Owen, R.; Macnaghten, P. \& Stilgoe, J. (2012). Responsible Research and Innovation: From science in society to science for society, with society". Science and Public Policy, 39(6), 751-760. https://doi. org/10.1093/scipol/scs093

Reed, M.S. (2016). The research impact handbook. Aberdeenshire: Fast Track Impact.

Rittelfeld, U; Cody, M. \& Vorderer, P. (2009). Serious games. Mechanisms and effects. New York: Routledge.

Romero, M., \& Gebera, O. T. (2015). Serious Games para el desarrollo de las competencias del siglo XXI. Revista de Educación a Distancia, (34). Retrieved from http://revistas.um.es/red/article/ view/233511/179431

Rubio, X. (2013). El pasado en tu sofá: juegos de simulación histórica en entornos computacionales portables. HER\&MUS, Heritage \& Museography, V(2), 55-62.

Tobias, S., Fletcher, J. D., \& Wind, A. P. (2014). Game-Based Learning. In M. Spector, M.D. Merrill, J. Elen \& M.J. Bishop (Eds.), Handbook of Research on Educational Communications and Technology (pp. 485-503). New York: Springer.

Vandercruysse, S.; Vandewaetere, M.; Cornillie, F. \& Clarebout, G. (2013). Students' Inclinations towards Games and Perceptions of Game-Based Learning (GBL). Education Technology Research and Development, 61(6), 927-950. https://doi.org/10.1007/s11423-013-9314-5

Wechselberger, U. (2013). Learning and enjoyment in serious gaming-contradiction or complement? Proceedings from DiGRA International Conference. Atlanta: DeFragging Game Studies. 
Wu, J- \& Lee, J. (2015). Climate change games as tools for education and engagement. Nature Climate Change, 5, 413-418. https://doi.org/10.1038/nclimate2566

Juan Luis Gonzalo-Iglesia

Universitat Rovira i Virgili, Department of Communication Studies, ASTERISC Communication Research Group

Email: juanluis.gonzalo@urv.cat ORCID: https://orcid.org/0000-0002-5682-1102

Natàlia Lozano-Monterrubio Universitat Rovira i Virgili, Department of Communication Studies, ASTERISC Communication Research Group

Email: natalia.lozano@urv.cat ORCID: https://orcid.org/0000-0001-9848-0257

Jordi Prades-Tena

Universitat Rovira i Virgili, Department of Communication Studies, ASTERISC Communication Research Group

Email: jordi.prades@urv.cat ORCID: https://orcid.org/0000-0001-5131-127X

Correspondência: Juan Luis Gonzalo-Iglesia Av. Catalunya, 35. 43002 Tarragona (Spain)

Data de submissão: Junho 2018

Data de avaliação: Julho 2018 Data de publicação: Setembro 2018 